\title{
Artykuey
}

KLIO. Czasopismo poświęcone dziejom Polski i powszechnym

PL ISSN 1643-8191, t. 23 (4)/2012, s. 7-24

\section{Roman Czaja}

(Toruń)

\section{Przenoszenie listów między miastami hanzeatyckimi w strefie battyckiej $w X I V-X V$ wieku}

tudia nad infrastrukturą związaną z wymianą korespondencji stanowią ważny element badań nad historią komunikacji w średniowieczu, gdyż nie sposób właściwie zrozumieć treści listów ani ich funkcji w obiegu informacji bez uwzględnienia sposobów i warunków ich transportu. Ponadto odpowiedź na pytania o infrastrukturę towarzyszącą wymianie korespondencji, o jej stopień profesjonalizacji i instytucjonalizacji, widoczny chociażby w pojawieniu się terminologii odnoszącej się do wyspecjalizowanych służb i zawodów, daje nam szansę rozpoznania dynamiki procesów komunikacji dokonujących się na określonym obszarze i w obrębie wspólnot oraz roli poszczególnych miast w systemach komunikacyjnych ${ }^{1}$.

Ze względu na dobry stan zachowania bazy źródłowej, na którą składają się zbiory korespondencji, księgi missivów i księgi rachunkowe oraz dużą intensywność kontaktów społecznych i gospodarczych, szczególnie ciekawym

${ }^{1}$ H.-D. Heimann, Räume und Routen in der Mitte Europas. Kommunikationspraxis und Raumerfassung, [w:] Raumerfassung und Raumbewusstsein im späten Mittelalter, hrsg. v. P. Moraw (Vorträge und Forschungen XLIX), Stuttgart 2002, s. 215; idem, Brievedregher. Kommunikations- und alltagsgeschichtliche Zugänge zur vormodernen Postgeschichte und Dienstleistungskultur, [w:] Kommunikations und Alltag in Spätmittelalter und Früher Neuzeit, hrsg. v. H. Hundsbichler (Veröffentlichungen des Instituts für Realienkunde des Mittelalters und der Frühen Neuzeit 15), Wien 1992, s. 259. 
obszarem badań nad komunikacją jest strefa hanzeatycka. Zdziwienie może budzić jednak fakt, że organizacyjne uwarunkowania obiegu korespondencji w strefie bałtyckiej w okresie gospodarczej dominacji Hanzy do tej pory nie stały się jeszcze przedmiotem systematycznych badań ${ }^{2}$. Nieco większe zainteresowania badaczy wywoływały jedynie obieg korespondencji w związku z organizacją zjazdów hanzeatyckich oraz tempo wymiany listów ${ }^{3}$.

Charakterystyczną cechą średniowiecznej korespondencji było funkcjonowanie równolegle różnych systemów przekazywania listów, co wynikało z faktu, że większość podmiotów uczestniczących w obiegu informacji (Kościół, władcy świeccy, miasta) tworzyła własną infrastrukturę komunikacyjną. Niezależnie od wyspecjalizowanych sług do przenoszenia korespondencji wykorzystywano także nadarzające się okazje: podróżnych, pielgrzymów, kupców, wędrujących rzemieślników, a nawet żebraków, czy wypływające z portu statki ${ }^{4}$. Uwzględnienie wszystkich form transportu listów przekracza ramy prezentowanego przyczynku, który poświęcony jest głównie wyspecjalizowanemu personelowi, świadczącemu usługi związane z obiegiem listów. Tym samym kwestionariusz badawczy poniższych rozważań ograniczony został do pytań o profesjonalizację infrastruktury komunikacyjnej oraz o funkcjonowanie systemu mającego cechy trwałości i regularności.

Z dotychczasowych badań wynika, że w Europie Północnej proces tworzenia personelu komunalnego wyspecjalizowanego w transporcie listów postępował z Zachodu na Wschód. W drugiej połowie XIII w. słudzy miejscy określani jako nuntius lub cursor pojawiają się w miastach flamandzkich. $\mathrm{O}$ ile pierwszy

2 Wprowadzające informacje zob. H.-D. Heimann, Verwaltung, Kommunikation, Dienstleistungskosten, [w:] Hanse - Städte - Bünde. Die sächsischen Städte zwischen Elbe und Weser um 1500, Bd. 2, hrsg. v. M. Puhle, Magdeburg 1996, s. 162-172.

3 H. Samsonowicz, Szybkość wymiany informacji wXVw., [w:] Nibil superfluum esse. Prace z dziejów średniowiecza ofiarowane Profesor Jadwidze Krzyżaniakowej, Poznań 2000, s. 429 n.; idem, Pismo, obraz, gtos. Formy przekazu informacji w świecie Hanzy, [w:] Scientia et amicitia. Studia poświęcone profesorowi Edwardowi Potkowskiemu, Warszawa-Pułtusk 1999, s. 168; M. Puhle, Das Gesandten-und Botenwesen der Hanse im späten Mittelalter, [w:] Deutsche Postgeschichte, hrsg. v. W. Lotz, Berlin 1989, s. 42-149; V. Henn, Innerhansische Kommunikationns- und Raumstrukturen. Umrisse einer neuen Forschungsaufgabe, [w:] Der hansische Sonderweg? Beiträge zur Sozialund Wirtschaftsgeschichte der Hanse, hrsg. v. S. Jenks, M. North, Köln-Weimar-Wien 1993, s. 255-279 .

${ }^{4}$ H.-D. Heimann, Räume und Routen..., s. 210; R. Czaja, Korrespondenz der preußischen Städte und des preußischen Bürgertums als Selbstzeugnis und Kommunikationsmedium im Spätmittelalter, [w:] Kommunikation mit dem Ich. Signaturen der Selbstzeugnisforschung an europäischen Beispielen des 12. bis 16. Jahrhunderts, hrsg. v. H.-D. Heimann, P. Monnet, Bochum 2004, s. 115. 
z tych terminów mógł oznaczać każdą osobę przenoszącą list lub informację ustną, to określenie cursor stosowano zwykle wobec osób zawodowo specjalizujących się w usługach komunikacyjnych. W tym czasie własnych posłańców posiadały także największe miasta Hanzy, Hamburg - pierwsza wzmianka z 1258 r. - oraz Lubeka, gdzie posłańcy miejscy wzmiankowani są od 1259 r. ${ }^{5} \mathrm{O}$ rozbudowie infrastruktury komunikacyjnej świadczy zapis w księdze kamlarskiej Lubeki, w której pod rokiem 1338 umieszczono wypłaty wynagrodzenia dla pięciu gońców oraz specjalnego posłańca rady określonego jako nuntius consulum ${ }^{6}$. Gońcy lubeccy podróżowali nie tyko w strefie hanzeatyckiej, ale wykorzystywano ich także do utrzymywania regularnych kontaktów między Lubeką i jej prokuratorem przy kurii papieskiej ${ }^{7}$. W źródłach z połowy XIV w. wzmiankowani są także posłańcy lub gońcy w innych miastach hanzeatyckich północnych i środkowych Niemiec. Z tego czasu pochodzą też pierwsze informacje o gońcu kantoru hanzeatyckiego w Brugii, który między innymi przenosił listy wzdłuż południowego wybrzeża Bałtyku aż do miast inflanckich. Na początku XV w. potwierdzona jest także obecność na tej trasie gońców lubeckich ${ }^{8}$.

Z 2. połowy XIV w. pochodzą pierwsze informacje o posłańcach (nuntius) w najstarszej księdze kamlarskiej Głównego Miasta Gdańska (1379$-1382)^{9}$. Z pewnością w połowie XIV w. z usług posłańców korzystały też naj-

5 Codex diplomaticus Lubecensis, Bd. II, T. 1, Lübeck 1858, s. 27 (Otto), s. 92 (Arnold w 1299 r.), s. 29 (nr 32) wzmiankowany jest ok. 1256 goniec przenoszący pieniądze i list dla prokuratora do Rzymu, nie został on jednak określony jako goniec lub posłaniec miejski; G. Ahrens, Das Botenwesen der Hamburger Kaufmannschaft (1517-1821), „Archiv für deutsche Postgeschichte”, Bd. 1: 1961, s. 28 n.

${ }^{6}$ Codex diplomaticus Lubecensis, Bd. II, T. 2, Lübeck 1858, s. 1078, 1080, 1081, 1082, gońcy: Soneke, Thideman Lorificus, Nicolaus de Darzowe, Detlef de Trente, Mathie Saxonis, jako posłaniec rady Hoton. Zwraca uwagę fakt, że w latach 1364-1374 jako goniec rady wzmiankowany jest Albert Sasse, być może potomek Mathie Saxona z 1338 r., zob. Das Lübecker Niederstadtbuch (1363-1399), T.1: Einleitung und Edition, hrsg. v. U. Simon, Köln-Weimar-Wien 2006, s. 46,1; 109,5; 152,6; 167,4; 183,1; 271,7; zob. też Kämmereirechnungen der Stadt Hamburg 1350-1400, hrsg. v. K. Koppmann, Hamburg 1869, s. 11 „nuncio dominorum Lubicensium” (1350 r.).

7 Codex diplomaticus Lubecensis, Bd. II, T. 1, s. 29 (nr 32); s. 89 (nr 106); ibidem, T. 2, s. 1078 .

8 Das Lübecker Niederstadtbuch (1363-1399)..., s. 130,9 - Thidericus, goniec Dortmundu; ibidem, s. 443,5 - Henneke Wunderke, goniec Magdeburga, gońcy określani terminem „cursor”; Kämmerei-Register der Stadt Riga 1348-1361, 1405-1474, hrsg. v. A. von Bulmerincq, Bd.1-2, Riga 1909-1913, gońcy określani terminami „loper” i „brefdregere”, s. 59, 85, 111; H.-D. Heimann, Brievedregher..., s. 263 n, 270.

9 M. Grulkowski, Najstarsza ksiega kamlarska Gtównego Miasta Gdańska jako źródto historyczne, [w:] Komturzy, rajcy, żupani, red. B. Śliwiński, Malbork 2005, s. 155. 
większe miasta inflanckie ${ }^{10}$. Wypłaty na rzecz osób (boten) przenoszących listy znajdujemy w najstarszych księgach kamlarskich Rewla (1363-1374, 1376-1380 $)^{11}$ oraz w księdze kamlarskiej Rygi prowadzonej od $1348 \mathrm{r}^{12} \mathrm{Na}$ uwage zasługuje jednak fakt, że w latach 60. i 70. XIV w. listy na trasie z Rewla do Dorpatu, która z punktu widzenia funkcjonowania korespondencji hanzeatyckiej w Inflantach miała zasadnicze znaczenie, przenosił sługa miejski ${ }^{13}$. Natomiast posłańcom zlecano w tym czasie transport listów do innych miast inflanckich i Turku. Większy stopień profesjonalizacji usług pocztowych widoczny jest w tym czasie w Rydze, której władze przenoszenie listów do innych miastach inflanckich (głównie Dorpatu i Parnawy) zlecały tylko gońcom ${ }^{14}$. Z ryskich i rewelskich rachunków kamlarskich nie wynika jednak, aby posłańcy przenoszący radzieckie listy mieli status zatrudnianych za roczny żołd sług miejskich. W 2. połowie XIV w. w Rydze bardzo wyraźnie zaznacza się proces rozbudowy miejskiego aparatu administracyjnego. Na początku XV w. wśród coraz liczniejszych sług zatrudnianych przez radę nadal brakowało jednak gońca wyspecjalizowanego w przenoszeniu listów. Nowością w porównaniu do sytuacji z połowy XIV w. jest zapisanie w 1410 r. i 1411 r. po raz pierwszy z imienia i nazwiska gońca (loper Cord Schellepepere), któremu rada Rygi zlecała przenoszenie listów ${ }^{15}$.

Na początku XV w. wyspecjalizowanego personelu do przenoszenia listów nie posiadała jeszcze Rada Starego Miasta Elbląga. Wprawdzie w księdze kamlarskiej z lat 1404-1414 r. w rocznych rozliczeniach regularnie pojawiają się wydatki na loper, pod tym terminem - wyjąwszy posłańców i gońców $\mathrm{z}$ innych miasta - rozumiano jednak rodzaj usługi, a nie trwale przypisany do funkcji personel. Podobnie do sytuacji w Rydze, nie znajdziemy w rachun-

${ }_{10}$ T. Salminen, The earliest Missives and Missivebooks of the Council of Reval. Some Remartks on the Management of Information in Fourteenth Century Town Administration, [w:] Verwaltung und Schriftlichkeit in den Hansestädten, hrsg. v. J. Sarnowsky (Hansische Studien XVI), Trier 2006, s. 131, z $1336 \mathrm{r}$. informacja o posłańcu przenoszącym list rady.

${ }_{11}$ Die ältesten Kämmereibücher der Stadt Reval 1363-1374, hrsg. v. O. Greifenhagen, Reval 1927, s. 23, 36, 35, 49, 53, 54, 76, 79 .

${ }^{12}$ Kämmerei-Register der Stadt Riga..., s. 33, 46, 47, znamienny jest fakt, że w księdze ryskiej określenia „cursor” i „nuncius” używane są jeszcze synonimicznie, podczas gdy w źródłach lubeckich w 2. połowie XIV w. wyraźnie różnicuje się znaczenie tych terminów.

13 Das Revaler Kämmereibuch von 1376 bis 1380, bearb. v. D. Heckmann, „Zeitschrift für Ostforschung”, Jg. 41: 1992, s. 211; Die ältesten Kämmereibücher, s. 23, 35, 49, $54,76$.

${ }_{14}$ Kämmerei-Register der Stadt Riga..., s. 33, 47, 46, 60 (zapisy z lat 1351-1358).

15 Ibidem, s. 96, 100. 
kach kamlarii elbląskiej zatrudnianych na stałe, za roczny żołd, gońców lub posłańców. Na początku XV w. przenoszenie listów i przekazywanie informacji w Eblągu zlecano personelowi ratusza: słudze miejskiemu, pisarzowi, kucharzowi rady, strażnikom, furmanowi, a nawet rzemieślnikowi opiekującemu sie zegarem miejskim. Sporadycznie do przykazywania listów wykorzystywano także uczniów ${ }^{16}$.

Z przedstawionego wyżej materiału źródłowego wynika, że do początku XV w. rady miast pruskich i inflanckich, w przeciwieństwie do miast północnoniemieckich, nie zatrudniały jeszcze sług wyspecjalizowanych w realizowaniu zadań komunikacyjnych. Inny obraz organizacji personelu związanego z obsługą korespondencji wyłania się ze źródeł z lat 30. XV w. W prowadzonej od 1432 księdze kamlarskiej Rewla w rocznych wydatkach rady systematycznie zapisywano wynagrodzenia w pieniądzu lub naturaliach dla sług miejskich $^{17}$. Do grupy tej nie zaliczano jednak posłańców, którzy pojawiają się w księdze po raz pierwszy w 1435 r., przy okazji sprawdzania stanu kominów w mieście. Na uwagę zasługuje fakt, że od końca lat 30 . XV w. zaznacza się systematyczny wzrost ich liczby. W 1438 r. wzmiankowany jest jeden posłaniec, w 1442 r. - dwóch, w 1452 r. - trzech, a w latach 1457-1466 - czterech $^{18}$. Natomiast od końca lat 60. do 1481 r. na usługach rady pozostawało pięciu stadesbote $^{19}$. W świetle zapisów zawartych w księdze kamlarskiej Rewla widoczna jest znacząca różnica w sposobie wynagradzania sług i posłańców miejskich. O ile ci pierwsi otrzymywali oprócz wynagrodzenia pieniężnego także naturalia, to posłańców wynagradzano tylko suknem na ubranie, niekiedy otrzymy-

16 Nowa ksiega rachunkowa Starego Miasta Elblaga 1404-1414 (dalej NKR), wyd. M. Pelech (Fontes TNT 72-73), Toruń 1987-1989, nr 7, 302, 455, 598, 770, 1185, 1262; zob. też informacje o uczniach dostarczających listy w: Das Marienburger Tresslerbuch der Jahre 1399-1409, hrsg. v. E. Joachim, Königsberg 1896, s. 8, 12, 24, 22, 29, 33, 68, 107, 153, 181, 245, 384; E. Rotter, Die Organisation des Briefverkehrs beim Deutschen Orden, [w:] Deutsche Postgeschichte, hrsg. v. W. Lotz, Berlin 1989, s. 23.

17 Kämmereibuch der Stadt Reval 1432-1463, hrsg. v. R. Vogelsang, Köln-Wien 1976-1979 , nr 13, 30, 69, 87, 129, 181, 197, 234, 249, 296, 474, 602, 785, 819, 837, 881, 912, 943, $1006,1047,1169$.

18 Ibidem, nr 152, 301, 565, 887, 1049, 1062, 1089, 1106, 1125, 1160, 1190; Kämmereibuch der Stadt Reval 1463-1507, hrsg. v. R.Vogelsang, Köln-Wien 1983, nr 1255, 1279.

19 Kämmereibuch der Stadt Reval 1463-1507, hrsg. v. R. Vogelsang, Köln-Wien 1983, nr 1289, 1362, 1499, 1636, 1673, 1751; ustalenie liczby posłańców w następnych latach nie jest możliwe, gdyż używana od 1482 r. formuła zapisu wydatków na zakup sukna dla nich nie uwzględniała ich liczby. 
wali także zboże lub odpowiednią sumę pieniędzy na jego zakup ${ }^{20}$. Nie wypłacano im natomiast stałego żołdu pieniężnego. Ubrania dla posłańców szyto z szarego sukna lubeckiego, podobnie jak dla strycharza, wójta targowego, adwokatów, woźnego sądowego, kucharza, sługi zatrudnionego w wapienniku, cieśli i kowala. W kontekście pytania o kondycję społeczną posłańców na uwagę zasługuje fakt, że lepszej jakości sukno angielskie lub niderlandzkie otrzymywali między innymi słudzy miejscy ${ }^{21}$. Na tej podstawie można sądzić, że posłańców zaliczono w Rewlu do niższej kategorii personelu zatrudnianego przez radę miejską i w przeciwieństwie do wielu miast niemieckich ich ubiór nie był traktowany jako forma reprezentacji miasta na zewnątrz ${ }^{22}$. Specjalizacja sług miejskich w późnośredniowiecznym Rewlu w zakresie przenoszenia korespondencji nie była jednak pełna, gdyż posłańców obciążano także innymi obowiązkami, m.in. pomagali oni w przeglądzie uzbrojenia obywateli, sprawdzaniu stanu kominów i zbieraniu podatków, a przenoszenie listów sporadycznie zlecano także innym sługom miejskim ${ }^{23}$. W rewelskich księgach kamlarskich widoczne jest także istotne rozróżnienie terminologiczne. Posłańców miejskich konsekwentnie określa się w nich jako stadesbote, natomiast termin loper, oznaczający gońca wyspecjalizowanego w przenoszeniu korespondencji stosowany jest wobec sług przynoszących listy $z$ innych miast ${ }^{24}$.

W ciągu 1. połowy XV w. coraz liczniej zaczynają się pojawiać w źródłach gońcy gdańscy. W tym czasie Gdańsk w coraz większym stopniu przejmował rolę węzłowego punktu komunikacyjnego między Zachodem Europy, a krajami położonymi w dorzeczu Wisły i wschodniej części regionu bałtyckiego. Poza tym pełnił także funkcję pośrednika w obiegu korespondencji urzędowej Hanzy z Inflantami, Litwą, Krakowem i Wrocławiem². W latach 30.

${ }^{20}$ Kämmereibuch der Stadt Reval 1432-1463, nr 887, 1049, 1089.

${ }^{21}$ Ibidem, nr 301, 611, 887, 946, 1062, 1089, 1106, 1125, 1160, 1190; Kämmereibuch der Stadt Reval 1463-1507, nr 1255, 1279, 1299, 1337, 1751, 1977.

${ }_{22} \mathrm{Na}$ temat ubioru posłańców zob. H.-D. Heimann, Brievedregher..., s. $280 \mathrm{n}$.

${ }_{23}$ Kämmereibuch der Stadt Reval 1432-1463, nr 152, 176, 829, 1125; Kämmereibuch der Stadt Reval 1463-1507, nr 1420, 1977.

${ }^{24}$ Kämmereibuch der Stadt Reval 1432-1463, nr 647, 694, 693, 741, 840, 884, 914, 944 , 973; Kämmereibuch der Stadt Reval 1463-1507, nr 1420, 1483, 1530, 1795, 1796, 1977.

25 R. Czaja, The regional and long-distance communication of Prussian towns in the 15 th century, [w:] Towns and Communication, vol. 2: Communication between Towns. Proceedings of the Meetings of the International Commission for the History of Towns (ICHT). London 2007-Lecce 2008 , ed. H. Houben, K. Toomaspoeg, Galatina 2011, s. 28; J. Sarnowsky, Die preußischen Städte in der Hanse, „Hansische Geschichtsblätter”, Jg. 112: 1994, s. 109. 
XV w. rada Głównego Miasta Gdańska wykorzystywała do przenoszenie listów na długich dystansach równocześnie pięciu gońców: Bernda von Wedelen, Clausa Wolff, Viifenden, Hansa Kruse i Hermana Osterrode ${ }^{26}$. Liczebność personelu zatrudnianego przez rady miast pruskich i inflanckich do przenoszenia listów kształtowała się więc podobnie jak w innych średnich i dużych miast Hanzy i poludniowych Niemiec ${ }^{27}$.

Dotychczasowe badania wskazują, że w strefie hanzeatyckiej nie funkcjonował jednolity system wynagradzania gońców. Statuty miasta Getyngi z początku XV w. uzależniały wielkość zapłaty za przenoszenie korespondencji od liczby przebytych mil. Ustawodawstwo określające wysokość opłaty dla gońca za przebycie jednej mili znane jest także z innych miast środkowych i południowych Niemiec ${ }^{28}$. Gońcy i posłańcy lubeccy otrzymywali w pierwszej po-

26 Th. Hirsch, Danzigs Handels- und Gewerbsgeschichte unter der Herrschaft des Deutschen Ordens, Leipzig 1858, s. 220 n., brak źródeł potwierdzających jego tezę, że jeden z gońców zatrudniany był specjalnie do obsługiwania ruchu pocztowego między Gdańskiem a Brugią i trasę tę pokonywał konno, poświadczona jest jedynie podróż Bernda von Wedelen na wozie (zob. niżej); Claus Wolff określony jako „loper und medeborger”, wzmiankowany w 1432 r. i 1438 r., Archiwum Państwowe w Gdańsku (dalej APGd.), sygn. 300,27/2, s. 48; Hansisches Urkundenbuch (dalej HUB), Bd. VII, 1, hrsg. v. H.-G. von Rundstedt, Weimar 1939, nr 411; Hanserecesse (dalej HR) 2. Abt., Bd. 1, hrsg. v. G. Frhr. v.d. Ropp, Leipzig 1876, nr 437; Bernd (Bernard) von Wedelen wzmiankowany jako „bote” w latach 1431-1436 i w 1439 jako sługa miejski, APGd., 327,2, s. 144 v., HR, 2. Abt. Bd. 1, s. 595, 596; HUB VII,1, nr 216, 500; Viifenden loper, HR, 2. Abt., Bd. II, nr 70, 171 (1437 r.); Hans Kruse, Liv-, Est-und Kurländisches Urkundenbuch (dalej LEKUB), Bd. 5, hrsg. v. F.G. von Bunge, Riga 1867, nr 2345, nr 2547; Die Berichte der Generalprokuratoren des Deutschen Ordens an der Kurie, Bd. III, hrsg. v. H. Koeppen, Göttingen 1966-1971, s. 48, 60, 640 n; ibidem, Bd. IV, hrsg. v. K. Forstreuter, H. Koeppen, Göttingen 1973-1976, s. 248; Herman Osterrode, HR, Abt. 2, Bd. I, nr 565, 595; ibidem, Bd. II, s. 106, 139, 211; Kämmerei-Register der Stadt Riga..., s. 212, 216.

27 Przykładowo w Kolonii między 1370 a 1381 r. zatrudniano równolegle 5 posłańców, w Getyndze na początku XV w. czterech, w Konstancji, Akwizgranie, Lüneburgu i Hildesheim od dwóch do trzech, w Strasburgu aż sześciu, zob. H.-D. Heimann, Verwaltung..., s. 168; idem, Räume und Routen..., s. 213; w Hamburgu w 2. połowie XIV w. rada regularnie opłacała trzech gońców, w 2. połowie XIV w. wśród regularnie opłacanych gońców pojawiają się zwykle cztery osoby, na stałym żołdzie rady pozostawało jednak dwóch lub trzech góńców, Kämmereirechnungen der Stadt Hamburg 1350-1400, s. 223, 271, 433, Kämmereirechnungen der Stadt Hamburg 1401-1470, hrsg. v. H. Koppmann, Hamburg 1873, s. s. 153-154, 158-159,187-188,193, 220, 225, 255-256, 260, 293-294, 299, 331-332, 338, 368-369, 376, 405-407, 412-413, 444-445, 452; Kämmereirechnungen der Stadt Hamburg 1471-1500, hrsg. v. K. Koppmann, Hamburg 1878, s. CXXXVI; rada Lubeki zatrudniała w połowie XIV w. 6 gońców, zob. przyp. 6; na usługach kantoru hanzeatyckiego w Brugii w 1440 r. pozostawało trzech gońców, Codex diplomaticus Lubecensis, Bd. VII, Lübeck 1885, nr 852, s. 875.

${ }^{28}$ H.-D. Heimann, Brievedregher..., s. 275 n; 
łowie XIV w. stały roczny żołd w monecie oraz ubranie ${ }^{29}$. W podobny sposób wynagradzano także gońców w Hamburgu ${ }^{30}$. Z zapisów w księgach rachunkowych miast pruskich i inflanckich wynika, że wynagrodzenie gońców składało się z dwóch elementów, stałego żołdu wypłacanego przez radę w naturaliach oraz akordowych opłat za zlecone i wykonane zadanie. Zwykle osoby przenoszące listy otrzymywały przedpłatę od rady zlecającej usługę oraz zapłatę od adresata. Nie dysponujemy źródłami zawierającymi informacje o opłatach za usługi świadczone przez gońców osobom prywatnym.

$\mathrm{Z}$ zapisów zawartych w księgach kamlarskich miast pruskich i inflanckich wynika, że opłata za przeniesienie listu zależna było od odległości, którą musiał przebyć goniec, nie była to jednak zależność wprost proporcjonalna. Gońcy wysyłani w latach 1404-1414 przez radę elbląską do Torunia (ok. $170 \mathrm{~km}$ ) otrzymywali najczęściej 12 szkojców, do Królewca (odległość około 100 km) - 8 szkojców, do Gdańska (odległość 60 km) - 6 szkojców, a do Braniewa (odległość $45 \mathrm{~km}$ ) - 4 szkojce. Sporadycznie wypłacano sumy różniące się od podanych wyżej, przy czym największe rozbieżności dotyczą gońców podróżujących z listami do Braniewa i do Królewca, którzy otrzymywali wynagrodzenie odpowiednio od 3 do 8 oraz od 10 do 14 szkojców $^{31}$. Niezależne od długości trasy, znacznie mniejsze wynagrodzenie otrzymywali przybywający do Elbląga gońcy z innych miast: $\mathrm{z}$ Wrocławia - 4 szkocje, z Torunia - 4, 3 lub 2 szkojce, z Lüneburga - 6 szkojców, z Królewca - 2 lub 3 szkojce, z Chełmna, Gdańska i Lubeki - 2 szkojce ${ }^{32}$. W XV w. w Rewlu goniec przynoszący listy z Lubeki (odległość około $1600 \mathrm{~km}$ ) otrzymywał najczęściej dwa guldeny lub trzy grzywny, chociaż zdarzały się i wypłaty wielkości jednego guldena i wahające się między pięcioma a ośmioma guldenami. Natomiast posłańcy przynoszący korespondencję z Rygi lub Dorpatu (ok. 310 km i 190 km) otrzymywali około 5-6 wiardunków ${ }^{33}$. Większe zróżnicowanie wypłat dla gońców daje się zauważyć w źródłach ryskich. Od lat 20. do 70. XV w. goniec przybywający

${ }^{29}$ Codex diplomaticus Lubecensis, Bd. I, T. 2, Lübeck 1858, s. 1078, 1080, 1081, 1082.

30 Kämmereirechnungen der Stadt Hamburg 1350-1400, s. 120, 121, 142, 162, 223, 237, 253, 254, 271, 289, 366, 433; Kämmereirechnungen der Stadt Hamburg 1471-1500, s. CXXXVI, w drugiej połowie XIV w. gońcy otrzymywali 4 grzywny, a wiek później 8 grzywien żołdu.

${ }^{31} \mathrm{NKR}, \mathrm{nr} 7,215,360,455,598,771,1016$.

$32 \mathrm{NKR}, \mathrm{nr} 7,215,360,455,598,771,1185,1280$; tylko 3 szkojce otrzymał goniec toruński, któremu rada elbląska zleciła przeniesienie listu do Królewca.

${ }^{33}$ Kämmereibuch der Stadt Reval 1432-1463, nr 647, 693, 694, 741, 813, 829, 840, 914, 944, 973, 1089; Kämmereibuch der Stadt Reval 1463-1507, nr 1370, 1420, 1483, 1641, 1795, 1796, 1873, 1977, 2012, 2082, 2281, 2387. 
z Lubeki otrzymywał najczęściej 1 grzywnę lub 1 guldena, rzadziej 5 wiardunków lub 2 grzywny. Jedną grzywnę wypłacano gońcowi przenoszącemu korespondencję na trasie do Walk i Dorpatu, ale też tyle samo lub 1 gulden otrzymywał goniec udający się do Lubeki, wyjątkowo jednak zdarzały się zapłaty niższe (pół grzywny) oraz wyższe, wynoszące dwie, czy nawet 10 grzywien lub 40 grzywien za przeniesienie specjalnych listów rady lubeckiej ${ }^{34}$. Niekiedy posłaniec z Gdańska otrzymywał dwukrotnie wyższe wynagrodzenie (6 wiardunków) niż posłańcy ze znacznie bardziej oddalonych miast: z Brugii - 4 lub dwa wiardunki, z Lubeki - 3 wiardunki, z Hamburga - 1 wiardunek, z Dortmundu -2 wiardunki ${ }^{35}$. Te znaczące dysproporcje wynikały zapewne $\mathrm{z}$ faktu, że gońcy przybywający z Flandrii i miast niemieckich otrzymywali po drodze wynagrodzenie od miast leżących na trasie ich marszu do Inflant. Natomiast posłańcy wysyłani do innych miast inflanckich lub Prus opłacani byli tylko przez nadawcę listu i adresata. Przedstawione analizy skłaniają do postawienia tezy, że w 1 . połowie XV wieku nie istniał jeszcze w pełni sformalizowany system taks za przenoszenie listów, lecz raczej należałoby mówić o opłatach określonych zwyczajem, których wielkość w zależności od okoliczności przesyłania listu i jego wagi mogła ulegać znaczącym wahaniom.

Formalnoprawny status gońców zatrudnianych przez rady miast nadbałtyckich różnił się wyraźnie od pozostałych sług miejskich, gdyż tworzyli oni nie tylko integralną część administracji ratuszowej, ale zobowiązani byli także do świadczenia usług na rzecz wszystkich mieszczan. Zatrudnienie przez radę, z czym wiązało się także zaprzysiężenie, zapewniało gońcowi wprawdzie niewielkie ryczałtowe wynagrodzenie, a niekiedy tylko ubranie, przede wszystkim jednak legitymizowało jego pozycję zawodową i czyniło go osobą zaufania publicznego $^{36}$. Jak wynika z listu wystawionego przez radę Głównego Miasta Gdańska w 1449 r., przyjęty na służbę posłaniec Matthias Merkel zobowiązany był do noszenia listów rady, mieszczan i kupców hanzeatyckich, otrzymywał także stat busse mit dem teken, czyli specjalnie oznakowaną torbę, pojemnik na listy, która symbolizowała jego funkcję ${ }^{37}$. Według podobnej formuły opisano zadania gońca kantoru hanzeatyckiego w Utrechcie. W 1455 r. starsi kanto-

${ }^{34}$ Kämmerei-Register der Stadt Riga..., s. 117, 132, 155, 162, 164, 169, 177, 179, 187, 188, 191, 212, 221, 239, 249, 250, 256, 269, 273, 275, 290, 320, 328, 332.

35 Ibidem, s. 9, 129, 188, 252.

${ }^{36}$ H.-D. Heimann, Räume und Routen..., s. 216; idem, Brievedregher..., s. 266 n; M. Puhle, Das Gesandten- und Botenwesen..., s. 52.

37 Th. Hirsch, Danzigs Handels- und Gewerbsgschichte..., s. 221. 
ru w liście do rady Lubeki informują o powierzeniu Antoniusowi Blakoolowi funkcji gońca enen gemeynen boden und loper i jednocześnie proszą o wsparcie dla niego, gdyż będzie przenosił listy rajców, mieszczan i kupców ${ }^{38}$. Także posłowie rady Lubeki podróżując wzdłuż południowego wybrzeża Bałtyku zbierali po drodze listy prywatne ${ }^{39}$.

Niewiele możemy powiedzieć na temat aktywności zawodowej poszczególnych gońców oraz ich pozycji społecznej. Spośród licznej grupy gdańskich posłańców z I połowy XV w. nieco więcej informacji posiadamy jedynie o działalności Hansa Kruse i Hermana Osterrode (1427-1449). Hans Kruse w latach 1419-1428 służył jako goniec zakonu krzyżackiego, nosił listy głównie między Prusami a kurią papieską ${ }^{40}$. Po dziesięcioletniej pracy na rzecz wielkiego mistrza przeszedł w 1429 r. na służbę rady Głównego Miasta Gdańska, w której pozostawał przynajmniej do 1442 r. Jako loper und bote przenosił listy na szlakach wzdłuż wybrzeża Bałtyku i Morza Północnego między Niderlandami, Bremą, Lubeką a Gdańskiem. Podróżował także na południe. 6 grudnia 1442 r. udał się w drogę z gdańskimi listami do Torunia, a stamtąd do Hildesheim i Soest ${ }^{41}$. Służąc jako goniec dorobił się pewnego majątku, na co wskazuje fakt, że w latach w latach 1431-1434 udzielił trzech pożyczek o wartości 55 grzywien ${ }^{42}$. Prawdopodobnie pod koniec swojego życia ponownie wstąpił na służbę wielkiego mistrza, gdyż jako goniec do prokuratora przy kurii rzymskiej pojawia się w 1448 r., a rok później wzmiankowany już jest jako zmarły ${ }^{43}$. Z usług Hermana Osterrode rada Głównego Miasta Gdańska korzystała w latach 1427-1449. Podróżował on głównie między Gdańskiem a Flandrią, Lubeką i Inf-

38 Codex diplomaticus Lubecensis, Bd. IX, Lübeck 1893, nr 284 „mit juwer heren breuen und der burger und cooplude juwer stad".

39 Ibidem, Bd. IV, Lübeck 1873, nr 641.

40 Berichte, Bd. IV, s. 248, jeszcze w 1430 r. przenosił list od Johana Rewe z Brugii dla wielkiego mistrza, jednak wówczas znajdował się już na służbie rady gdańskiej; J.-E. Beuttel, $\operatorname{Der} G e-$ neralprokurator des Deutschen Ordens an der Römischen Kurie. Amt, Funktionen, personelles Umfeld und Finanzierung (Quellen und Studien zur Geschichte des Deutschen Ordens 55), Marburg 1999 , s. $126,196 \mathrm{n}$.

${ }^{41}$ APGd., 300 D, 24, nr 95, 124; HR, Abt. 1, Bd. VIII, hrsg. v., K. Koppmann, Leipzig 1897, nr 602; HR, Abt. 2, Bd. I, nr 105; ibidem, Bd. II, nr 411, 434, 448, 532, 533, 535, 537; w styczniu 1442 r. wyruszył jeszcze z listami rady Gdańska i wielkiego mistrza do Brugii, zob. HR, Abt. 2, Bd. II, nr 533, s. 453 n, nr 537.

42 APGd., 300, 43/1a, k. 170, 184, 286v, 317; ibidem, 300,43/1b, k. 192 v, w latach 1434-1438 zaciągnął pożyczki na sumę 15 grzywien. Za informacje te dziękuję Panu Cezaremu Kardaszowi.

43 J.-E. Beuttel, Der Generalprokurator..., s. 197 n. 
lantami ${ }^{44}$. Herman Osterrode jest pierwszym znanym gońcem, który służbę na rzecz Gdańska łączył z obowiązkami gońca Hanzy, tym terminem najczęściej określano posłańców kantoru hanzeatyckiego w Brugii. W 1439 r. został on określony jako eyn bote und louffer des gemeynen kaufmans und der stete von der hanse ${ }^{45}$, a w 1446 r. rada Gdańska pisała o nim jako unser und des gemenen Copmans dener unde loper ${ }^{46}$. Można przypuszczać, że w 1. połowie XV w. tego typu połączenie stanowisk nie było niczym niezwykłym. W 1449 r. rada Gdańska polecała Lubece swojego sługę i gońca Matthiasa Merkela do przyjęcia na gońca i posłańca Hanzy: to juwen und des gmeynen Copman von der dutschen hense mit juw vorkerende baden und loper willet vpnemen ${ }^{47}$. Na trasie między Rewlem, Rygą, Gdańskiem i Europą Zachodnią podróżował w latach 1447-1457 inny, bliżej nieznany, gdański goniec Bertold, który jednak nie pojawia się w źródłach jako goniec hanzeatycki ${ }^{48}$. Wydaje się, że wśród osób przenoszących listy, posłańcy działający na dłuższych trasach, a w szczególności gońcy kantoru brugijskiego, zajmowali najwyższą pozycję. Na taką możliwość wskazuje list starszych kantoru do rady Lubeki z 1459 r., w którym wychwalają długoletnią służbę gońca Henninga na rzecz kupców, z troską podkreślają, że utracił zdrowie i proszą o zapewnienie mu utrzymania na starość ${ }^{49}$. Gońcy kantoru, podobnie, jak gońcy władców, traktowani byli jako członkowie świty kantoru, w czasie szczególnych uroczystości towarzyszyli starszym i kupcom ${ }^{50}$.

Obowiązki posłańców nie ograniczały się tylko do przenoszenia korespondencji, gdyż najczęściej przekazywali także ustną informację mundlike

${ }^{44}$ HR, Abt. 2, Bd. I, s. 480, 496, 530; ibidem, Bd. II, s. 106, 139, 211, 232; LECUB, Bd. IX, hrsg. v. H. Hildebrand, Riga-Moskwa 1889, IX, nr 245, 422, 539; Kämmerei-Register der Stadt Riga..., s. 212, 216.

45 HR, Abt. 2, Bd. II, nr 289.

46 APGd., sygn. 300,27/4, s. 226; po raz ostatni jako goniec kantoru brugijskiego jest wzmiankowany w listach starszych kantoru do rad Gdańska i Lubeki z 8 VI 1449 r., Codex diplomaticus Lubecensis, Bd. VIII, Lübeck 1889, nr 618, s. 664; Hanserecesse 2. Abt., Bd. III, hrsg. v. G. von der Ropp, Leipzig 1881, s. 404 (nr 533).

47 Th. Hirsch, Danzigs Handels- und Gewerbsgeschichte..., s. 221, przyp. 917.

48 LECUB, X, hrsg. v. Ph. Schwartz, Riga-Moskwa 1896, nr 295, s. 200; HUB, Bd. VIII, hrsg. v. W. Stein, Leipzig 1899, nr 564; Kämmereibuch der Stadt Reval 1432-1463, nr 840, 914, 944, 973; Kämmerei-Register der Stadt Riga..., s. 249.

49 Codex diplomaticus Lubecensis, Bd. IX, nr 668; Henning przynajmniej od 1448 r. służył jako goniec kantoru, zob. Codex diplomaticus Lubecensis, Bd. VIII, Lübeck 1889, nr 497.

$50 \mathrm{~W} 1440$ r. trzech gońców kantoru towarzyszyło starszym i kupcom w czasie uroczystego zawarcia ugody z władcą Flandrii, Codex diplomaticus Lubecensis, Bd. VII, s. 875. 
bodscop, która uzupełniała treść listu ${ }^{51}$. Słowa zapisane przez gdańskiego rajcę Marquarta Knake w 1454 r. w liście z Lubeki do rady Gdańska Ok werd ju bertold de loper wol segende, wskazujące na ustny przekaz powierzony gońcowi można uznać za stały element formularza późnośredniowiecznego listu ${ }^{52}$. Przykład lubeckiego posłańca Hartwiga von Seelen, który w latach 1444-1452 regularnie przenosił listy na trasie z Flandrii, przez Lubekę do Rygi i Rewla, wskazuje, że szczególnie doświadczonym gońcom oprócz dostarczania listów zlecano także misje o charakterze dyplomatycznym ${ }^{53}$. W listopadzie 1448 r. Hartwig został wysłany przez radę Lubeki z listami do arcybiskupa w Nowogrodzie Wielkim. Oprócz korespondencji lubeccy rajcy przekazali mu także instrukcję, która określała ogólne zasady działania szybko i bez zwłoki - a także zawierała informacje o punktach kontaktowych do odbioru pieniędzy i korespondencji w miastach inflanckich oraz wskazówki, jak prowadzić rozmowy z radami Rygi, Dorpatu, Rewla oraz w Nowogrodzie ${ }^{54}$. Do zadań posłańców należało również przenoszenie pieniędzy, czy to dla rajców uczestniczących w zjazdach lub rokowaniach hanzeatyckich, czy też prywatnych płatności zlecanych przez mieszczan ${ }^{55}$. Powierzano im także transport wartościowych artykułów handlowych, np. cennych tkanin i korzeni oraz prezentów, wymienianych między radami miejskimi ${ }^{56}$. Gońcom podróżującym na dalekosiężnych trasach mieszczanie powierzali załatwienie w ich imieniu spraw z mieszkańcami innych miast. Przykładowo, w 1448 r.Johannes Stumme, mieszkaniec Cloppenburga pożyczył konia goń-

${ }^{51} \mathrm{Na}$ temat połączenia słowa i pisma w późnośredniowiecznej korespondencji zob. M. Jukker, Vertrauen, Symbolik, Reziprozität. Das Korrrespondenzwesen eidgenössischer Städte im Spätmittelalter als kommunikative Praxis, „Zeitschrift für Historische Forschung“, Bd. 34, 2 (2007), s. 197 n; H. Boockmann, Die Briefe des Deutschordenshochmeister..., [in:] H.-D. Heimann, Kommunikationspraxis und Korrespondenzwesen im Mittelalter und in der Renaissance, Zürich 1998, s. 107; H.-D. Heimann, Brievedregher..., s. 165.

52 Scriptores rerum Prussicarum, hrsg. v. Th. Hirsch, E. Strehlke, M. Toeppen, Bd. IV, Leipzig 1872, s. 638, 639.

${ }^{53}$ LEKUB, Bd. X, s. 13 (nr 22), 355, 359, 360, 419; Kämmereibuch der Stadt Reval 1432-1463, nr 647, 694, 741; Kämmerei-Register der Stadt Riga..., s. 249, 250; w 1455 r. Hartwig przenosił listy lubeckiej rady do króla Danii, HR, Abt. 2, Bd. IV, nr 348, s. 257.

${ }^{54}$ HR, Abt. 2, Bd. III, hrsg. v. G. von der Ropp, Leizpig 1881, nr 418, 419, 515.

55 APGd., sygn. 300,27/2, s. 48; ibidem, 300,27/4, s. 226; HR, Abt. 1, Bd. I, s. 480; HUB, Bd. VIII, nr 564 .

${ }^{56}$ HUB, Bd.7/1, nr 216; HR, Abt. III, Bd. 2, hrsg. v. D. Schäffer, Leipzig 1888, nr 51, s. 44; H.-D. Heimann, Brievedregher..., s. 165. 
cowi lubeckiemu Hartwigowi von Seelen w zamian za pomoc w załatwieniu sporu z mieszczanami Rygi przed radą Lubeki ${ }^{57}$.

Można przypuszczać, że w strefie hanzeatyckiej podróże posłańców niekiedy odbywały się według wcześniej uzgodnionej marszruty, co umożliwiało między innymi ich skorelowanie z trasami podróży delegatów rad na zjazdy hanzeatyckie. Na taką możliwość wskazuje list pisany z Lubeki przez Heinricha Vorratha, burmistrza Gdańska i jednocześnie posła na zjazd Hanzy, który list wysłany do rady gdańskiej w dniu 26 grudnia 1437 r. pisał w dwóch częściach. W pierwszej części listu, przygotowanej z pewnością przed 24 grudnia, informował radę, że zwleka z wyjazdem do Bremy i do 26 grudnia będzie czekał na loper ut Prussen, ponieważ chciałby za jego pośrednictwem otrzymać aktualne wiadomości. Z drugiej części listu, pisanej 26 grudnia dowiadujemy się, że goniec przybył do Lubeki dwa dni wcześniej i przekazał listy oraz informacje ${ }^{58}$.

Gońcy najczęściej podróżowali pieszo lub na wozie - z $1431 \mathrm{r}$. pochodzi informacja o gdańskim posłańcu Berndzie von Wedelen, który wozem przemierzał trasę z Brugii do Gdańska ${ }^{59}$. Z początku XV w. pochodzą informację o posłańcach konnych, którym zlecano szczególnie pilne zadania ${ }^{60}$. Rozróżnienie między gońcami podróżującymi pieszo, loper, a posłańcami konnymi, rydenboden, pojawia się także w księdze kamlarskiej Starego Miasta Elbląga. W połowie XV w. posłańca konnego utrzymywała rada Głównego Miasta Gdańska ${ }^{61}$. Transport lądowy był wprawdzie wolniejszą niż morski, ale stosunkowo niezawodną formą przekazywania korespondencji. W wypadku listów pilnych lub szczególnie ważnych przesyłano je równolegle pewniejszą drogą lądową oraz szybszą, ale ryzykowniejszą drogą morską ${ }^{62}$. Korzystanie z różnych środków transportu sprawiało, że czas przekazywania listu bywał bardzo zróżnicowany.

57 Codex diplomaticus Lubecensis, Bd. IX, Lübeck 1893, nr 410.

58 Hanserecesse, Abt. 2, Bd. II, nr 171, s. 146.

59 APGd., 300,27, 2, s. 144 v, 152.

${ }^{60}$ Codex diplomaticus Lubecensis, Bd. V, Lübeck 1877, nr 289 (1409 r.), nr 429 (1422 r.) „rada Lubeki prosi rady Lüneburga i Wismaru o przesyłanie odpowiedzi na jej listy przez «jueme ridenne boden »"; ibidem, Bd. VII, Lübeck 1885, nr 190 (1428 r.), wzmiankowany konny posłaniec Stralsundu

${ }^{61} \mathrm{NKR}, \mathrm{nr}$ 455, 598, 1185; Th. Hirsch, Danzigs Handels- und Gewerbsgeschichte..., s. 221.

${ }^{62}$ Codex diplomaticus Prussicus, Bd. V, hrsg. v. J. Voigt, Königsberg 1854, s. 176, list rady Lubeki do wielkiego mistrza z 1 IX 1402 r.w sprawie rokowań z królową Małgorzatą został wysłany lądem i morzem „desser bref is twe, een to lande, de ander to water up dat erer een yo vord kome”; M. Puhle, Das Gesandten- und Botenwesen..., s. 53; H.-D. Heimann, Räume und Routen..., s. 213. 
Podróż piesza z Brugii do Gdańska trwała około pięciu tygodni, a do Rygi około sześciu, siedmiu tygodni, możliwe było także przekazanie listu drogą morską w ciągu dwóch lub trzech tygodni. Przykładowo, listy wysłane przez radę Gdańska 14 lipca 1438 r. (prawdopodobnie drogą morską) do kantoru hanzeatyckiego w Antwerpii dotarły już 31 lipca, natomiast te same listy posłaniec Herman Osterrode doniósł trzy tygodnie później (ok. 23 sierpnia) ${ }^{63}$.

Analiza procesu profesjonalizacji infrastruktury komunikacyjnej powinna uwzględniać wyraźnie zaznaczającą się w 1. połowie XV w. dynamikę rozwoju korespondencji. Struktura bogatego zbioru korespondencji zakonu krzyżackiego w Prusach wskazuje, że liczba listów gwałtowanie zaczęła rosnąć od drugiego dziesięciolecia XV w., a w Rewlu proces ten zaznaczał się już w pierwszym dziesięcioleciu tegoż stulecia ${ }^{64}$. Podobne zjawisko widoczne jest także w natężeniu korespondencji gdańskiej. W latach 20. XV w. kancelaria rady Głównego Miasta Gdańska wysyłała przeciętnie w ciągu roku 17 listów, w następnym dziesięcioleciu średnia roczna wynosiła już 42 listy, a w latach 40. 51 listów. Podobnie przedstawia się dynamika korespondencji kierowanej do Gdańska. O ile w latach 20. rada otrzymywała przeciętnie w ciągu roku 6 listów spoza Prus, to w latach 30. i 40. rocznie wpływało 33-35 listów ${ }^{65}$. Wraz ze wzrostem liczby listów i znaczenia słowa pisanego w procesie komunikacji musiało się także zwiększać zapotrzebowanie na wykwalifikowanych gońców.

$\mathrm{Z}$ problemem profesjonalizacji infrastruktury łączy się przede wszystkim pytanie o stałe trasy, regularnie i permanentnie obsługiwane przez gońców. W dotychczasowej literaturze przedmiotu wskazuje się, że tego typu system obsługi w strefie hanzeatyckiej wykształcił się dopiero w drugiej połowie

${ }^{63}$ HR, Abt. 2, Bd. II, nr 264, 265; APGd., 300,27/2, s. 180, w 1437 r. Gdańsk wysłał pilny list do Rygi morzem, a drugi za pośrednictwem Henryka, pisarza mistrza inflanckiego, lądem; przykładowo wysłana przez Lubekę do Rewla korespondencja z 15 III 1484 r. w sprawie zawarcia pokoju z Francją nie dotarła do adresata, dlatego ponownie wysłano ją drogą morską i lądową HR, Abt. III, Bd. 1, nr 507, s. 414., zob. też. H. Samsonowicz, Szybkość wymiany..., s. 429 n.; idem, Pismo, obraz, gtos..., s. 168 n., szacuje przeciętność dzienną szybkość podróży lądowej na ok. 25 km, a morskiej na ok. $47 \mathrm{~km}$. Uwzględniając postój gońców w miastach położonych na trasie podróży, dane te potwierdzają przedstawione wyżej czasy podróży.

${ }^{64}$ H. Boockmann, Die Briefe..., s. 108; T. Salminen, Bücher, Konzepte und Briefe: Schriftlichkeit in der Kommunikation des Revaler Rates von Stadtschreiber Hermannus bis Joachim Muter (1375-1456), [w:] Die Stadt im europäischen Nordosten. Kulturbeziehungen von der Ausbreitung des Lübischen Rechts bis zur Aufklärung, hrsg. v. R. Schweizer u. W. Bastman-Bühner, Helsinki-Lübeck 2001, s. 164.

${ }^{65}$ APGd., syg. 300,24/1-4;. 300,24/1-4; 300, D. 
XVI w. ${ }^{66}$ Niewątpliwie możemy mówić o sztafetowym systemie przekazywania listów urzędowych, który już w 2. połowie XIV w. funkcjonował w ramach poszczególnych regionów. Taka formy obiegu korespondencji jest najlepiej poświadczona dla miast wendyjskich, pruskich i inflanckich. Listy między radami Lubeki a Rostoku i Stralsundu przesyłane były za pośrednictwem gońców Wismaru $^{67}$. W państwie zakonnym w Prusach rada elbląska pośredniczyła w wymianie listów hanzeatyckich między Gdańskiem a Braniewem i Królewcem ${ }^{68}$. W miastach inflanckich korespondencja między Rygą a Rewlem była przekazywana za pośrednictwem Dorpatu ${ }^{69}$. Należy jednak podkreślić, że w ramach sztafet regionalnych przekazywano doraźną korespondencję. Poza tym nie tworzyły one sieci powiązań ogarniających całą strefę bałtycką. Wyjątek w tym względzie stanowiło jedynie pośrednictwo miast pruskich w wymianie korespondencji między Lubeką a miastami inflanckimi, które na przełomie XIV i XV w. uważane było za utrwalony zwyczaj ${ }^{70}$.

Wydaje się, że elementy regularnego obiegu korespondencji można dostrzec w największym stopniu na szlaku prowadzącym wzdłuż południowych wybrzeży Morza Północnego i Bałtyku z Brugii, przez Lubekę, miasta pomorskie i pruskie do Inflant. Przenoszenie korespondencji miast inflanckich z Zachodem przez posłańców lubeckich lub posłańców kantoru brugijskiego poświadczają liczne wzmianki od połowy XIV w., a w księdze ryskiej pod rokiem 1357/1358 po raz pierwszy pojawia się informacja o cursor mercatorum Theutonicorum ${ }^{71}$. Powstaje jednak pytanie, od kiedy ruch gońców na tej trasie z doraźnego, wynikającego z konieczności wysłania określonej korespondencji lub informacji, przekształcił się w regularny? Interesującą wskazówkę w tej sprawie zawiera korespondencja miast inflanckich. Rajcy Rygi w liście do Rewla z 2 stycznia 1418 r., zapraszając na zjazd do Wolmaru, planowany na 23 stycznia tegoż roku, informują, a właściwie tłumaczą się, że nie posiadają najnowszych informacji z Zachodu, gdyż nie przybył jeszcze goniec z Flandrii: so en es hir noch gen loper ut Flandern umme lant gekommen adder von

${ }^{66}$ M. Puhle, Das Gesandten- und Botenwesen..., s. 53; H.-D. Heimann, Räume und Routen..., s. 229.

${ }^{67}$ Codex diplomaticus Lubecensis, Bd. V, nr 629; ibidem, Bd. VI, Lübeck 1881, nr 16, 26, 367, 419, 441, 453, 597, 653, 772; ibidem, Bd. VII, nr 122, 159, 190, 277; ibidem, Bd. IX, nr 484. ${ }^{68}$ Szerzej na ten temat zob. R. Czaja, The regional and..., s. 23; J. Sarnowsky, Die preußischen Städte..., s. 109-111.

69 Zob. przyp. 13 i 14.

${ }^{70}$ LECUB, Bd. IV, s. 349.

${ }^{71}$ Kämmerei-Register der Stadt Riga..., s. 59, 85, 163, 164, 168, 176, 180. 
den overseeschen Steden, also dat wi sunderlikes noch gene tidinge hebbe $e^{72}$. W liście z 6 marca 1441 r. rada Dorpatu ponagla radę Rewla, że jeżeli chciałaby wysłać listy by des lopers kupmane to powinna szybko dostarczyć korespondencję, gdyż goniec wkrótce wyruszy w drogę ${ }^{73}$. W świetle tych listów oczekiwanie na gońca przynoszącego wiadomości lub zabierającego korespondencję w miesiącach zimowych wydaje się czymś zwyczajnym. Na szczególne podkreślenie zasługuje fragment listu wysłanego przez kantor brugijski do Gdańska z 5 grudnia 1439 r., w którym kupcy hanzeatyccy proszą gdańską radę o pomoc w uzyskaniu od wielkiego mistrza glejtu na wybrzeżu żmudzkim dla gońca hanzeatyckiego i wprost piszą o ,starym zwyczaju”, jakim jest wysyłanie gońca $\mathrm{z}$ listami do Prus i Inflant: alse dat na alder costume woenlick es, mittes coopman breve van der henze utghesand und belastet, omme de in Pruyssen und Lifflande to brengen ${ }^{74}$.

Podobnego typu informacja pojawia się przy okazji zatrudnienia Antoniusa Blakoola jako gońca kantoru hanzeatyckiego w Utrechcie, do którego obowiązków należało przenoszenie listów między kantorem, Lubeką i Gdańskiem $^{75}$.

Informacje zawarte w przenoszonej korespondencji oraz w księgach kamlarskich wskazują najczęściej na pobyt posłańców hanzeatyckich nad Dźwiną w okolicach Bożego Narodzenia, a w Rewlu w styczniu i lutym ${ }^{76}$. Regularne podróże gońców odbywały się więc w czasie, gdy zakazana były żegluga (11 XI-22 II). Można więc założyć, że około listopada lub w początkach grudnia goniec wyruszał z Flandrii lub Lubeki i, podróżując wzdłuż wybrzeża między przełomem roku a początkiem marca, docierał do Rygi - niekiedy Rewla. $\mathrm{Na}$ funkcjonowanie tego systemu wskazuje także dobrze poświadczona grupa gońców hanzeatyckich: wspomniany już wyżej Herman Osterrode, Hartwig von Seelen, goniec lubecki Lubeki (1444-1448), Bertold, być może Andreas, Heinrich von Vennen, posłaniec kantoru hanzeatyckiego w latach 1486-1490, przenoszących regularnie listy na trasie między Flandrią a Inflantami ${ }^{77}$. O ska-

${ }^{72}$ LECUB, Bd. V, nr 2190.

73 LECUB, Bd. IX, nr 700.

${ }_{74}$ HR, Abt. 2, Bd. II, hrsg. G. von der Ropp, Leipzig 1878, nr 289; LECUB IX, nr 539.

75 Codex diplomaticus Lubecensis, Bd. IX, Lübeck 1893, nr 284 (1455 r.).

${ }^{76}$ Kämmereibuch der Stadt Reval 1432-1463, nr 647, 693, 694, 741, 813, 840, 914, 944, 973; Kämmereibuch der Stadt Reval 1463-1507, nr 1420, 1530, 1795, 1796; Kämmerei-Register der Stadt Riga..., s. 87, 96, 117, 121, 163, 164, 168, 176, 180, 188, 204, 236, 249.

77 LECUB, Bd. XI nr 723; Kämmerei-Register der Stadt Riga..., s. 249, 250: HR, Abt 3, Bd. II, nr, 51, 181; Kämmereibuch der Stadt Reval 1432-1463, nr 647, 694, 741, 813, 840, 914, 944, 
li usług pocztowych świadczonych przez gońców podróżujących na szlaku wzdłuż południowego wybrzeża Bałtyku świadczy fakt, że przy gońcu lubeckim Hansie Backer, aresztowanym w 1462 r. przez urzędników zakonu krzyżackiego w Lęborku znaleziono około sto listów ${ }^{78}$.

Podsumowując przedstawione wyżej uwagi, można stwierdzić, że z pewnością w XV w. sposób zatrudniania gońców i wykonywanie przez nich zadań związanych z przenoszeniem listów nie zostały jeszcze objęte ustawodawstwem komunalnym. W tym czasie nie dokonała się więc w strefie hanzeatyckiej formalno-prawna profesjonalizacja infrastruktury wspierającej obieg korespondencji. Wydaje się jednak, że w ciągu 1. połowy XV w. wraz z upowszechnieniem się funkcji gońca i wyraźnie zaznaczającym się wzrostem liczby gońców zatrudnianych przez miasta pruskie i inflanckie, pojawiły się w strefie bałtyckiej elementy permanentnie funkcjonującego systemu. Zwrócić należy uwagę przede wszystkim na względnie stałe opłaty dla gońców, określane jednak przez zwyczaj, a nie przez formalne taksowanie przestrzeni. Od lat 30. XV w. pojawia się coraz więcej przesłanek wskazujących na regularne, w określonej porze, kursowanie posłańców na trasie między Flandrią a Prusami i Inflantami. Można więc przypuszczać, że miasta hanzeatyckie, dążąc do optymalizacji komunikacji między skrajnymi punktami hanzeatyckiego systemu handlowego, czyli Flandrią i Inflantami, stworzyły system komunikacji, który był rozwiązaniem nowatorskim w skali całej Europy, gdyż według Heinza-Dietera Heimanna kooperatywne formy organizacji transportu listów na ściśle określonych trasach należą do trzeciej fazy organizacji pracy gońców, która zaczyna się w Europie od drugiej dekady XVI wieku' ${ }^{79}$.

973; Kämmereibuch der Stadt Reval 1463-1507, nr 2012, 2082; Andreas w 1444 r. wzmiankowany jako posłaniec kantoru w Brugii, posłaniec („bote”) i goniec („loepere”) o tym imieniu w latach 1436-1447 r. pojawia się w księdze kamlarskiej Rewla, Kämmereibuch der Stadt Reval 1432-1463, nr 76, 693; HR, Abt. 2, Bd. III, nr 15.

${ }_{78}$ Codex diplomaticus Lubecensis, Bd. X, Lübeck 1898, nr 216, 242.

79 H.-D. Heimann, Räume und Routen..., s. 215; M. Puhle, Das Gesandten- und Botenwesen..., s. 53, wskazuje, że regularny system komunikacji w strefie hanzeatyckiej powstał dopiero w 2. połowie XVI w. 


\section{Transferring of letters between the hanseatic towns in the Baltic area in the 13th and 15 th. $c$.}

(Summary)

The aim of the paper is to present the infrastructure of transferring letters in the Baltic area in the late Middle Ages. Author focuses its interest on the question of professionalization process of communication services and of the system with features of stability and regularity. The first part of the article is devoted to the development of specialized staff to carry letters. The first pieces of information about couriers and messengers in the towns of Flanders and northern Germany are to be found in the sources from the second half of the thirteenth century. In the Prussian and Livonian towns the process of creating professional staff to carry correspondence ended only in the first half of the fifteenth century. The Author points out the differences between the Hanseatic towns in the methods of paying of couriers and messengers who were required to provide services to the city councils and the burghers. Supposedly, Hanseatic towns created a system of regular communication between Livonian Towns (Riga, Revel) and Flanders, in which the major role played by messengers called in the sources as "the servant and courier of the Hanseatic merchant". This system of communication must be considered innovative on the European scale.

Roman Czaja Instytut Historii i Archiwistyki UMK rc@umk.pl 